\title{
PENGEMBANGAN MEDIA PEMBELAJARAN BERBASIS AUGMENTED REALITY
}

\author{
Ilmawan Mustaqim, S.Pd.T., M.T. ${ }^{1}$, Nanang Kurniawan ${ }^{2}$ \\ ${ }^{1}$ Jurusan Pendidikan Teknik Elektro FT UNY, ${ }^{2}$ Jurusan Pendidikan Teknik Elektro FT UNY \\ Email: ilmawan@uny.ac.id
}

\begin{abstract}
Good learning process must contain interactive aspects, fun, challenging, motivating and provide more space for students to develop their creativity and independence, according to their talents and interests of students. An exciting medium of learning also indispensable for vocational students, because in vocational learning prioritize practical rather than theoretical. Need to be considered in the selection of media that is the purpose of learning, effective, easy to obtain, learners, use, not rigid, cost, and quality. One of the developments of instructional media which still new is learning media by using Augmented Reality. Augmented Reality is a merger of real-world applications to the virtual world in the form of two-dimensional and three-dimensional projected in a real environment at the same time. Augmented Reality can be used in entertainment, medical, mechanical, and learning media. Augmented Reality can be built using Vuforia and Unity 3D software. The final result in the form of interactive learning media with Augmented Reality.
\end{abstract}

Keywords : learning, augmented reality, education, vocational, software development

\begin{abstract}
ABSTRAK
Proses pembelajaran yang baik haruslah memuat aspek interaktif, menyenangkan, menantang, memotivasi dan memberikan ruang yang lebih bagi siswa untuk dapat mengembangkan kreativitas dan kemandirian, sesuai dengan bakat dan minat siswa. Media pembelajaran yang menarik juga sangat diperlukan bagi siswa SMK, dikarenakan dalam pembelajaran SMK lebih mengutamakan praktikum dari pada teori. Perlu dipertimbangkan dalam pemilihan media yaitu tujuan pembelajaran, efektif, mudah diperoleh, peserta didik, penggunaan, tidak kaku, biaya, dan kualitas. Salah satu perkembangan media pembelajaran yang saat ini masih baru adalah media pembelajaran dengan menggunakan Augmented Reality. Augmented Reality merupakan aplikasi penggabungan dunia nyata dengan dunia maya dalam bentuk dua dimensi maupun tiga dimensi yang diproyeksikan dalam sebuah lingkungan nyata dalam waktu yang bersamaan. Augmented Reality dapat digunakan dalam hiburan, kedokteran, mekanik, dan media pembelajaran. Augmented Reality dapat dibangun dengan menggunakan bantuan software Vuforia dan Unity 3D. Hasil akhir berupa media pembelajaran interaktif dengan Augmented Reality.
\end{abstract}

Kata Kunci: augmented reality, pembelajaran, media, pengembangan

\section{PENDAHULUAN}

Media pendidikan sangat diperlukan sebagai perantara penyampai pesan, guna meminimalkan kegagalan selama proses komunikasi berlangsung. Bethany (2014) mengemukakan bahwa proses belajar adalah proses penyampaian pesan/materi dari pemberi pesan (guru) ke penerima pesan (peserta didik). Proses pengubahan pesan/materi menjadi simbol komunikasi baik verbal maupun nonverbal disebut encoding. Penafsiran simbol komunikasi oleh peserta didik disebut decoding. Dalam proses penyampaian pesan/materi tersebut ada kalanya berhasil, ada kalanya tidak. Kegagalan dalam proses komunikasi ini disebut noise/bariere. Media pembelajaran sangat diperlukan guru untuk membantu menyampaikan materi dalam sebuah proses pembelajaran.

Proses pembelajaran yang baik haruslah memuat aspek interaktif, menyenangkan, menantang, memotivasi dan memberikan ruang yang lebih bagi siswa untuk dapat mengembangkan kreativitas dan kemandirian, sesuai dengan bakat dan minat siswa. Meskipun guru hanya sebagai fasilitator dalam sebuah pembelajaran, dan siswa yang dituntut untuk lebih aktif, guru harus mampu membuat suasana pembelajaran yang menyenangkan untuk merangsang siswa lebih aktif dalam belajar. Kegiatan pembelajaran yang menyenangkan sangat dipengaruhi oleh 
berbagai faktor, salah satunya adalah pemilihan media pembelajaran yang digunakan haruslah dapat menarik bagi siswa untuk belajar, interaktif saat digunakan, namun tidak mengurangi esensi materi yang disampaikan.

Perkembangan teknologi yang semakin maju, tentunya berpengaruh kedalam berbagai sektor kehidupan manusia. Perkembangan ini turut berperan dalam perkembangan sebuah media pembelajaran. Media pembelajaran menjadi semakin menarik dan semakin ringkas meskipun tidak mengurangi esensi dari materi. Salah satu perkembangan media pembelajaran yang saat ini masih baru adalah media pembelajaran dengan menggunakan Augmented Reality.

Augmented Reality merupakan aplikasi penggabungan dunia nyata dengan dunia maya dalam bentuk dua dimensi maupun tiga dimensi yang diproyeksikan dalam sebuah lingkungan nyata dalam waktu yang bersamaan. Augmented Reality sering juga disebut dengan realitas tertambat. Aplikasi ini sering diterapkan dalam sebuah game. Seperti yang dilansir dari inet.detik.com (2015) menyebutkan bahwa Xbox Development dari Microsoft tidak hanya menghadirkan game dalam bentuk Virtual Reality namun juga menghadirkan game dalam bentuk Augmented Reality. Teknologi yang masih tergolong baru ini masih sedikit pemanfaatannya di Indonesia. Dilansir dari republika.co.id (2015) menyebutkan bahwa penggunaan Augmented Reality di Indonesia belum terlalu besar. Masih minimnya pengetahuan masyarakat mengenai teknologi ini menjadi salah satu penyebabnya.

Dengan menggunakan Augmented Reality sebagai salah satu alternatif media pembelajaran, diharapkan dalam sebuah kegiatan pembelajaran dapat lebih menarik bagi siswa. Manfaat lain yang diperoleh adalah media pembelajaran yang lebih maju dengan memanfaatkan perkembangan teknologi saat ini. Melalui Augmented Reality dapat menjadi salah satu solusi untuk mengatasi modul ataupun trainer yang cukup mahal dan tidak mampu dibeli oleh sekolah. Siswa tetap dapat melakukan praktikum dengan melihat barang seperti aslinya, namun dalam bentuk virtual.

\section{KELEBIHAN DAN KEKURANGAN}

Dalam sebuah sistem pasti terdapat kelebihan dan kekurangan, tak terkecuali Augmented Reality. Kelebihan dari Augmented Reality adalah sebagai berikut : 1) Lebih interaktif, 2) Efektif dalam penggunaan, 3) Dapat diimplementasikan secara luas dalam berbagai media, 4) Modeling obyek yang yang sederhana, karena hanya menampilkan beberapa obyek, 5) Pembuatan yang tidak memakan terlalu banyak biaya, 6) Mudah untuk dioperasikan. Sedangkan kekurangan dari Augmented Reality adalah: 1) Sensitif dengan perubahan sudut pandang, 2) Pembuat belum terlalu banyak, 3) Membutuhkan banyak memori pada peralatan yang dipasang.

\section{PEMANFAATAN AUGMENTED REALITY}

Berbeda dengan Virtual Reality (VR) yang menambahkan obyek nyata pada sebuah obyek maya, Augmented Reality (AR) adalah menambahkan obyek maya ke dalam obyek nyata dalam waktu yang bersamaan. Menurut Raajan (2014) menyebutkan bahwa Augmented Reality pertama kali digunakan pada tahun 1957-1962 oleh seorang sinematografer bernama Norton Heilig, yang diberi nama Sensorama. Sensorama merupakan sebuah simulator yang dapat mensimulasikan visual, getaran, dan bau.

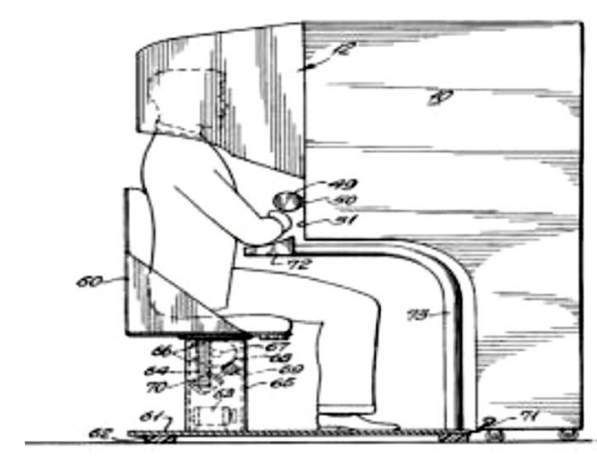

Gambar 1. Sensorama

(Sumber : Raajan:2014) 
Pada tahun 1966, Sutherland melakukan claim telah menemukan head-mounted display yang sering disingkat menjadi HMD. HMD menjadi cikal bakal pemanfaatan Augmented Reality yang menggunakan perangkat keras dan dipasang di kepala pengguna. Contoh pemanfaatan HMD pada saat ini adalah Google Glass. Di era 2000-an tepatnya tahun 2009, Sqoosha memperkenalkan FLARToolkit, yang merupakan hasil pengembangan dari ARToolkit. FLARToolkit dapat digunakan untuk menambahkan Augmented Reality pada website, karena keluaran yang dihasilkan FLARToolkit berbentuk Flash. Pada tahun 2010, Acrossair membenamkan teknologi AR pada I-Phone 3GS.

Augmented Reality dapat digunakan dalam berbagai kegiatan, seperti presentasi, memperkirakan suatu obyek, peralatan perangsang kinerja, mensimulasikan suatu kinerja alat, dan lain-lain. Beberapa contoh tersebut merupakan gambaran pemanfaatan Augmented Reality secara umum.

\section{Navigasi Telepon Genggam}

Merebaknya penggunaan smartphone dewasa ini turut menggeser penggunaan berbagai peralatan analog yang sebelumnya ramai dipergunakan. Saat ini sudah sangat praktis, hampir semua peralatan yang sebelumnya kita harus membawanya satu persatu, sekarang sudah beralih menjadi bentuk aplikasi. Semua sudah berada dalam genggaman tangan dalam bentuk aplikasi yang dibenamkan pada smartphone.

Berbagai aplikasi ini sangat mendukung dalam kehidupan kita sehari-hari. Terdapat tiga sistem operasi smartphone yang mendukung terhadap teknologi Augmented Reality melalui antar muka pemrograman aplikasi masingmasing. Kamera pada smartphone digunakan sebagai sumber aliran data visual, yang dipadukan dengan sensor lain dan aplikasi yang digunakan pada smartphone.

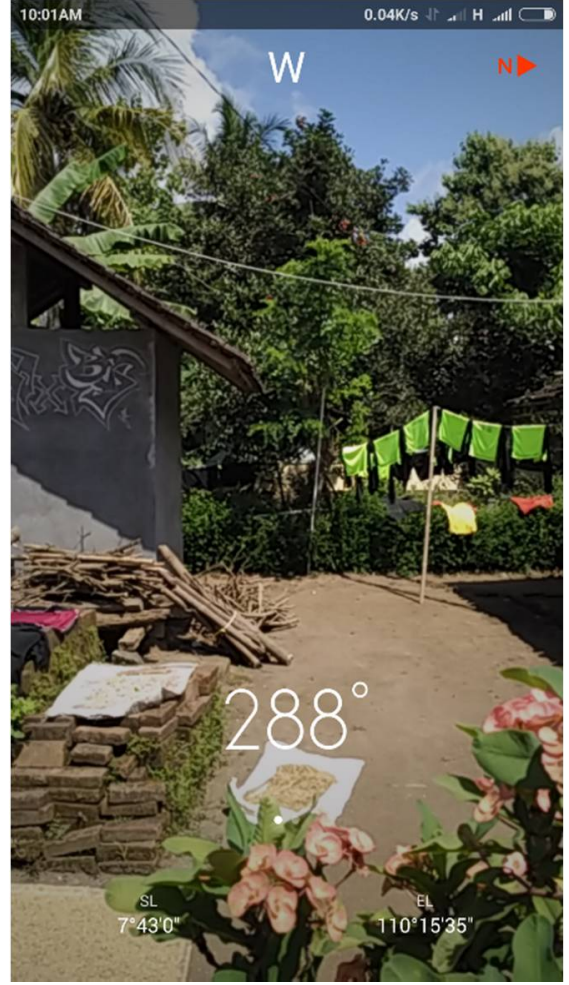

Gambar 2. AR pada kompas

(Sumber : Aplikasi kompas Mi4i:2016)

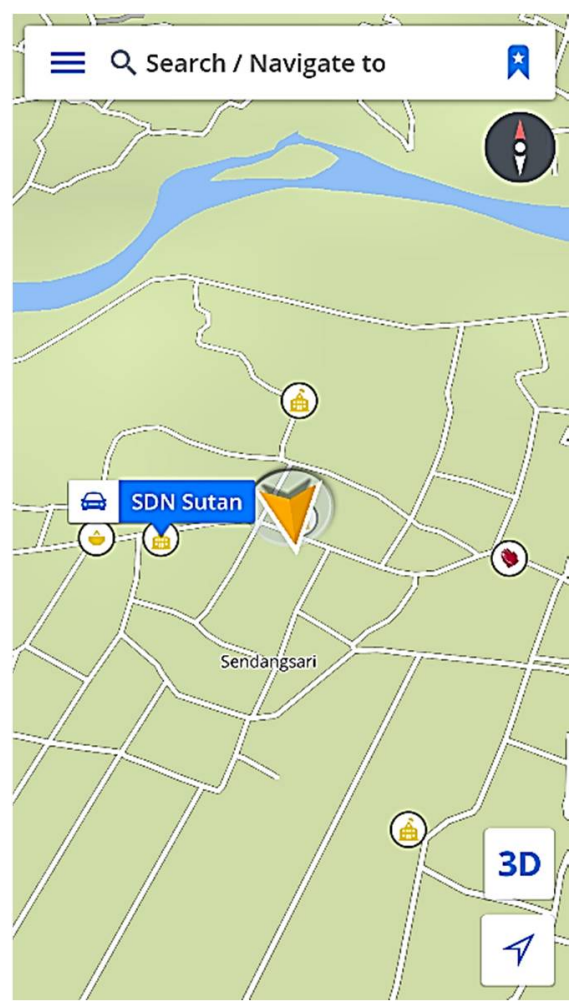

Gambar 3. AR pada peta online (Sumber : Aplikasi Sygic Mi4i:2016) 


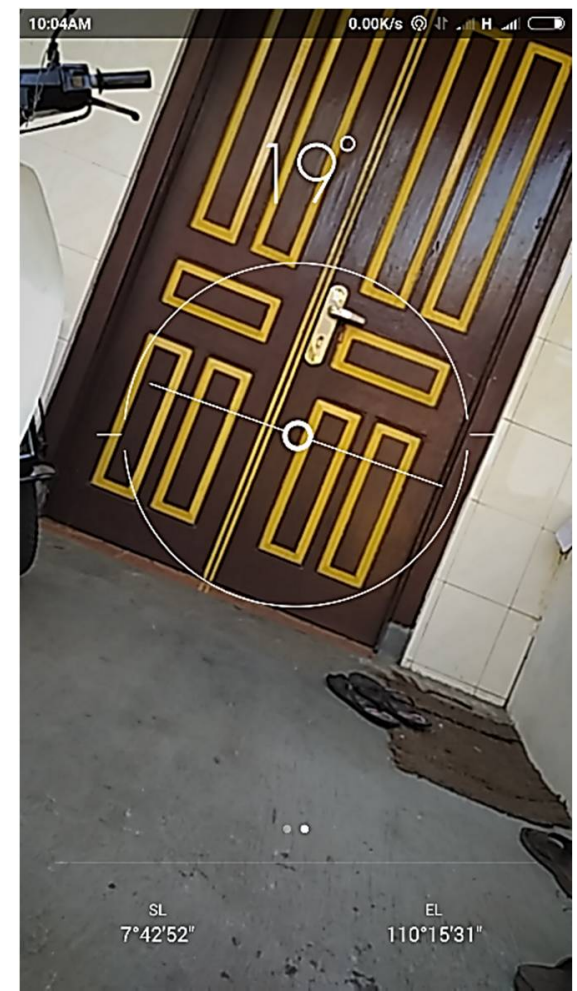

Gambar 4. AR pada kemiringan

(Sumber : Aplikasi kompas Mi4i:2016)

\section{Hiburan}

Industri hiburan merupakan kawasan pertama yang telah menggunakan Augmented Reality. Dalam sebuah siaran berita, teknologi ini paling sering digunakan. Seorang presenter yang berada di studio berdiri didepan layar berwarna hijau atau biru. Pencitraan yang asli digabungkan dengan peta buatan komputer menggunakan teknik chroma-keying atau sering disebut dengan green screen. Presenter seolaholah berinteraksi dengan obyek yang sebenarnya hanya berupa virtual, seperti dalam siaran cuaca. Peta cuaca yang terus berubah disekitar presenter.

Dengan menggunakan teknologi ini, iklan dapat ditampilkan dalam acara pertandingan sepak bola maupun dalam pertandingan bulu tangkis di tengah-tengah lapangan, dengan syarat tidak ada pemain yang menggunakan kostum berwarna hijau atau biru, karena akan terutup oleh iklan yang dimasukkan.

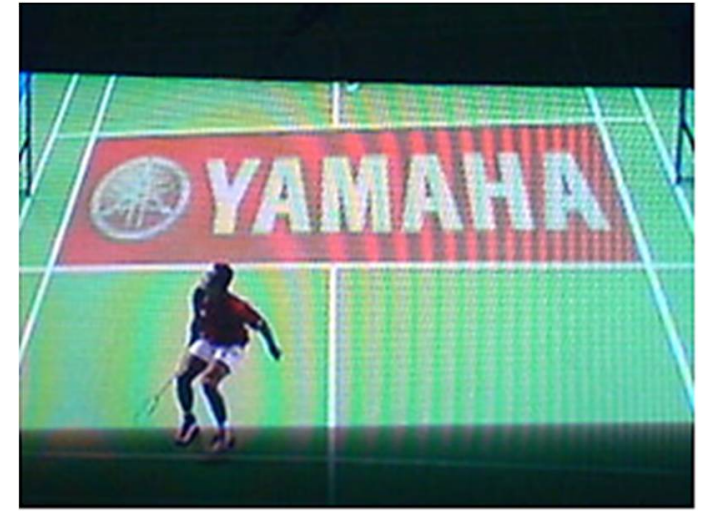

Gambar 5. AR dalam iklan olahraga (Sumber: Google.co.id:2011)

\section{Kedokteran}

Dalam dunia kedokteran, Augmented Reality sangat diperlukan. AR digunakan untuk melakukan simulasi operasi, untuk memberikan gambaran visual dari organ dalam manusia, untuk melakukan pelatihan dokter sebelum melakukan pembedahan yang sesungguhnya. Obyek maya dapat juga mengidentifikasi organ dalam tubuh dan lokasi tepatnya untuk menghindari kesalahan.

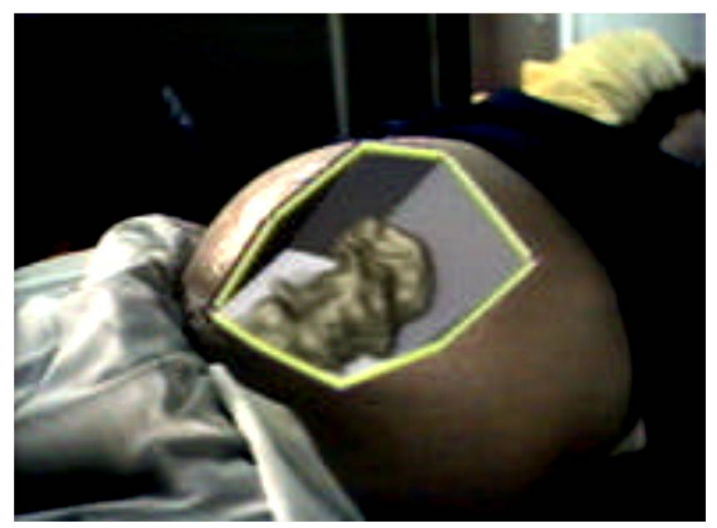

Gambar 6. AR untuk simulasi Janin

(Sumber: Azuma:1997)

\section{Pabrik dan perbaikan}

Pemanfaatan Augmented Reality disektor lain adalah pabrik pembuatan, perakitan, dan perawatan mesin yang sangat kompleks. Instruktur maupun teknisi akan lebih mudah untuk mengerti setiap bagian mesin, sehingga mempercepat pekerjaan. Bagian mesin akan diproyeksikan dalam bentuk tiga dimensi secara virtual, bukan seperti buku manual dengan tulisan dan gambar yang cenderung susah untuk 
dimengerti. Gambar tiga dimensi yang dibentuk menyerupai bentuk asli pada bagian mesin, sekaligus instruksi berupa animasi bagimana cara memasang ataupun melepas.

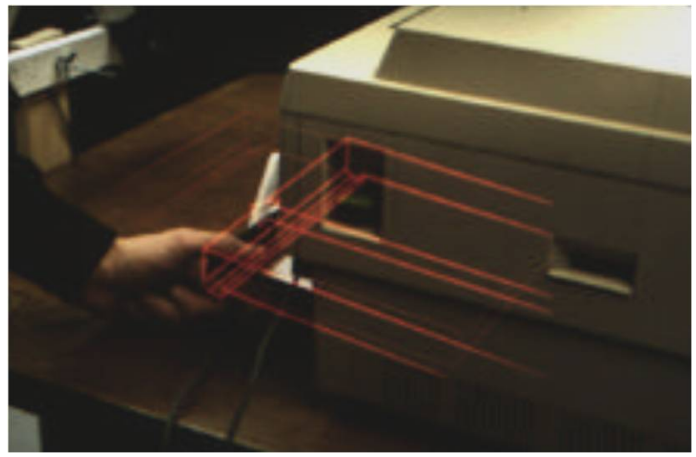

Gambar 7. AR sebagai pengganti User manual book

(Sumber : Azuma:1997)

\section{Perencanaan bagian robot}

Dalam bidang robotika, untuk merakit sebuah robot yang rumit, maka sangat diperlukan sebuah simulasi. Simulasi disajikan dalam bentuk virtual, yang menyajikan visual akhir dari robot yang dirakit.

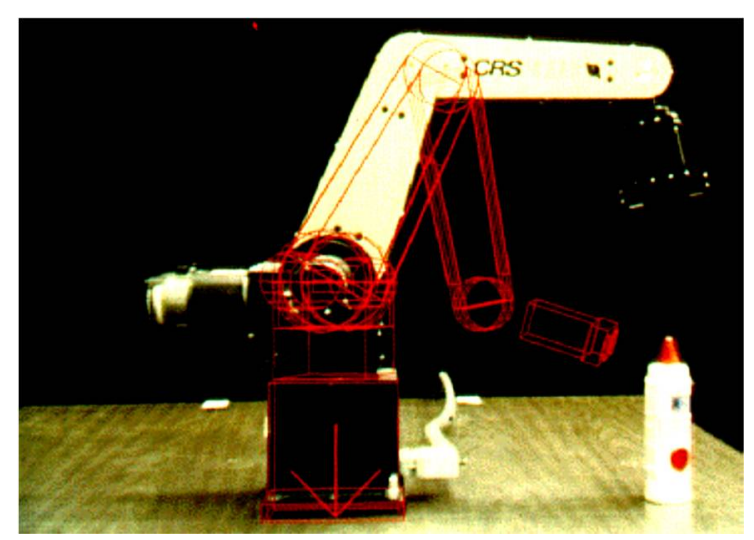

Gambar 7. AR dalam simulasi robotik

(Sumber: Azuma:1997)

\section{Media Pembelajaran}

Augmented Reality dapat menjadi salah satu alternatif media pembelajaran di sekolah. Siswa perlu adanya pembaruan media pembelajaran sehingga tidak terpaku pada media pembelajaran yang konvensional. Media menjadi faktor yang tak kalah penting dalam keberhasilan materi yang disampaikan.
Elisa (2014) menggunakan teknologi Augmented Reality untuk membuat media pembelajaran teknik digital berupa modul praktikum. Perangkat praktikum Teknik Digital yang digunakan dalam modul adalah Leybold Kit, berupa papan trainer Leybold beserta gerbang-gerbang logika.

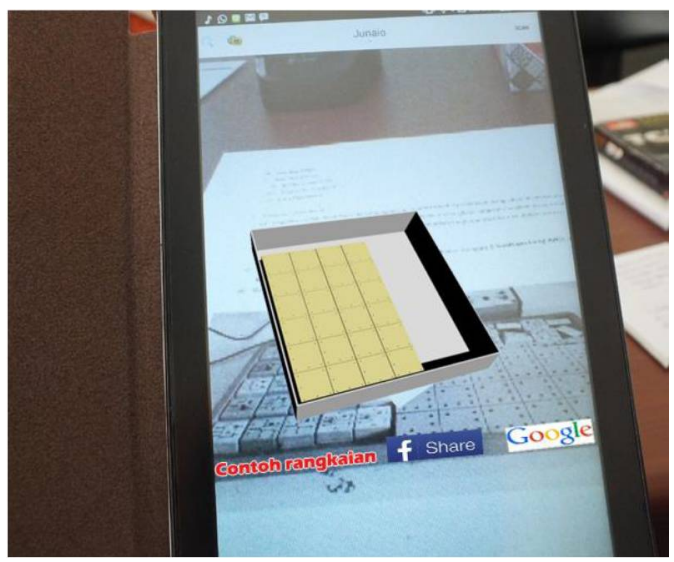

Gambar 8. Tampilan aplikasi media pembelajaran berbasis AR

(Sumber: Elisa: 2014)

Sigit (2014) menggunakan Augmented Reality sebagai sarana pembelajaran interaktif berbasis android bagi siswa sekolah dasar untuk menyampaikan materi mengenai sistem tata surya. Supaya dapat menampilkan obyek virtual, digunakan marker sebagai penanda setiap obyek. Marker dibuat dalam lembaran seperti buku yang mempunyai sampul depan, isi, dan sampul belakang. Gambar dalam marker berupa obyek tiga dimensi yang dicetak, sehingga saat aplikasi diarahkan pada marker, obyek tiga dimensi seolah-olah terlihat keluar dari gambar marker.

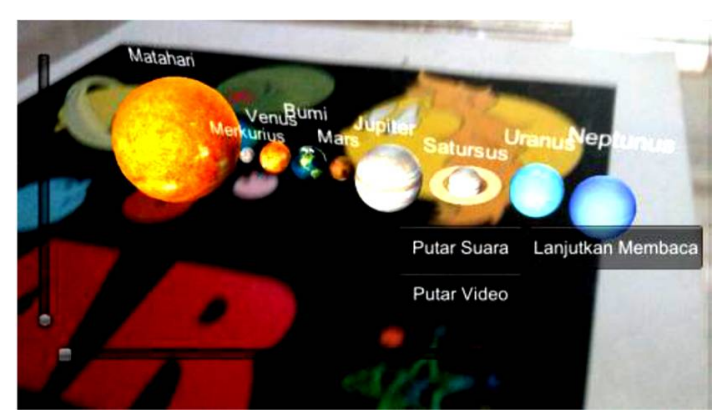

Gambar 9. AR menampilkan planet 3D

(Sumber: Sigit:2014) 
I Dewa (2015) menggunakan Augmented Reality untuk memperkenalkan binatang bagi siswa TK. Marker bergambar binatang yang dicetak di atas kertas dibuat agar menarik bagi siswa TK. Ketika aplikasi diarahkan diatas marker, maka otomatis gambar binatang secara tiga dimensi akan seolah keluar dari dalam gambar, yang disertai dengan animasi pergerakan binatang. Melalui media pembelajaran ini diharapkan siswa TK dapat lebih antusias dalam mempelajari berbagai binatang. Selain untuk mengenalkan binatang kepada siswa, dengan media ini juga secara tidak langsung mengajarkan siswa untuk dapat menggunakan teknologi yang saat ini sedang berkembang.

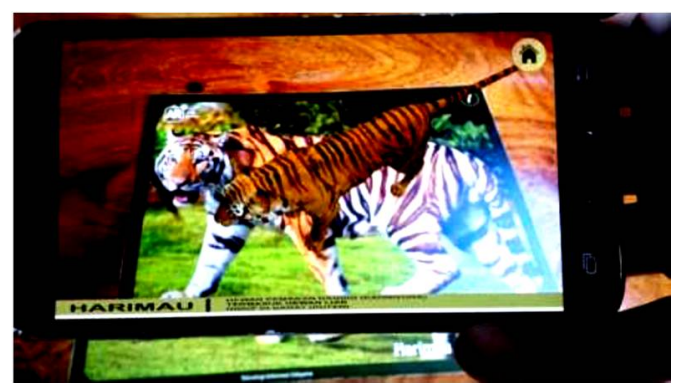

Gambar 10. AR menampilkan gambar harimau.

(Sumber: I Dewa: 2015)

Media pembelajaran yang menarik juga sangat diperlukan bagi siswa SMK, dikarenakan dalam pembelajaran SMK lebih mengutamakan praktikum daripada teori. Persentase praktikum sebanyak $70 \%$ dan teori sebanyak 30\%. Dengan persentase praktikum yang lebih banyak, tentunya siswa akan lebih banyak menggunakan trainer atau modul praktikum, sementara modul atau trainer praktikum sangat terbatas ketersediaannya, sehingga kegiatan praktikum kurang maksimal.

Hal tersebut dapat diatasi dengan cara membuat modul atau trainer praktikum berbentuk virtual, sehingga siswa tetap dapat melakukan latihan praktikum diluar jam pelajaran di sekolah. Diharapkan prestasi siswa dapat lebih meningkat dengan adanya aplikasi praktikum secara virtual.

\section{CARA KERJA AUGMENTED REALITY}

Pada dasarnya, prinsip kerja Augmented Reality adalah pelacakan (tracking) dan dan rekonstruksi (reconstruction). Pada mulanya marker dideteksi menggunakan kamera. Cara deteksi dapat melibatkan berbagai macam algoritma missal edge detection, atau algoritma image processing lainnya. Data yang diperoleh dari proses pelacakan digunakan dalam rekonstruksi sistem koordinat di dunia nyata. Disamping menambahkan obyek kedalam lingkungan nyata, Augmented Reality juga dapat menghilangkan obyek nyata dalam bentuk virtual. Dengan menutupi obyek nyata tersebut dengan disain grafis sesuai lingkungannya, maka obyek nyata akan tersembunyi dari pengguna.

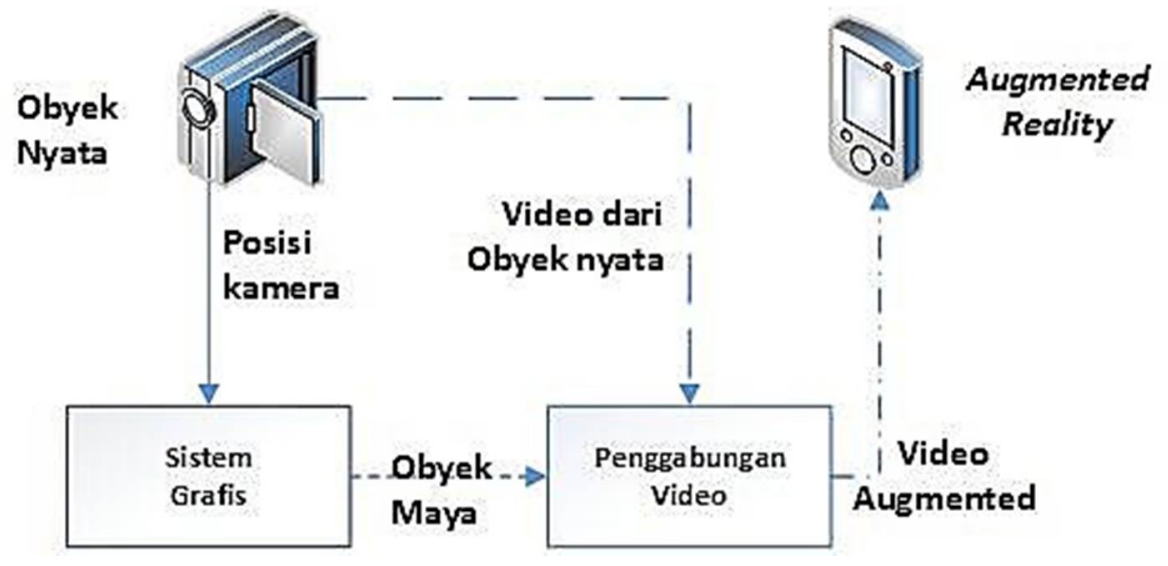

Gambar 11. Diagram kerja Augmented Reality

Pada Gambar 11. terlihat bagaimana Augmented Reality bekerja. Menurut penelitian
Azuma (1997) menyebutkan bahwa sebuah Augmented Reality sedikitnya memiliki tiga 
karakteristik: 1) kombinasi nyata dengan maya, 2) interaktif dan dalam waktu nyata, 3) disajikan dalam bentuk tiga Dimensi.

Obyek nyata beserta marker yang sudah dipasang akan dideteksi oleh kamera, kemudian informasi dari kamera diteruskan ke sistem grafis berupa posisi kamera, yang berisi data grafis obyek virtual. Informasi berupa video obyek nyata diteruskan ke penggabungan video. Dalam sistem grafis, posisi kamera menentukan sudut pandang obyek maya yang akan ditampilkan. Dalam penggabungan video, informasi dari sistem grafis digabung dengan video nyata dari kamera. Hasil penggabungan akan ditampilkan pada layar smartphone yang sudah berupa Augmented Reality.

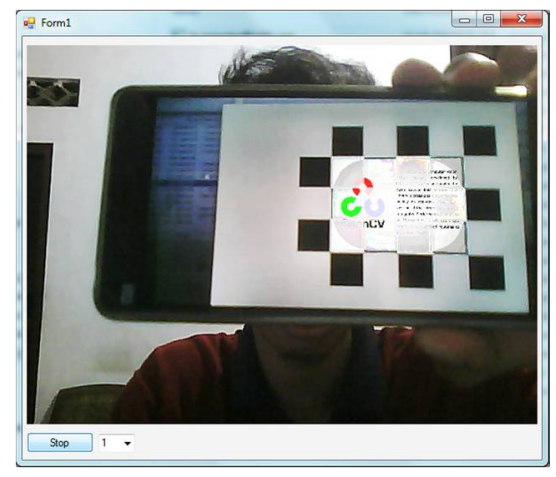

Gambar 12. Hasil penggabungan obyek nyata dengan obyek maya.

(Sumber: OpenCV: 2016)

Gambar 12. memperlihatkan hasil dari penggabungan obyek nyata dengan obyek maya. Marker dideteksi menggunakan kamera, namun tidak semua bagian marker yang dibaca, melainkan hanya sebagain saja. Apabila titik penting dari marker sudah didapat, maka tidak perlu membaca seluruh marker yang ada.

\section{MEDIA PEMBELAJARAN}

Media menjadi faktor yang penting dalam kegiatan pembelajaran. Melaui media guru dapat terbantu dalam menyampaikan materi. Kegiatan pembelajaran menjadi lebih hidup dengan adanya media. Siswa turut merasakan manfaat dengan adanya media yang digunakan, namun sebuah media belum tentu dapat menjangkau seluruh kalangan siswa.
Keterbatasan trainer atau modul yang digunakan sebagai media pembelajaran menjadi salah satu penghambatnya. Hal lain yang juga menjadi penghambat adalah karekteristik dan kemampuan siswa yang berbeda-beda dalam menyerap materi yang disampaikan.

Menurut Rudi Susilana dan Cepi Riyana (2009) mengatakan bahwa kesesuaian media dengan siswa menjadi dasar pertimbangan utama, sebab hampir tidak ada satu media yang dapat memenuhi semua tingkatan usia. Perlu perancangan yang matang sehingga media dapat tepat sasaran dalam penggunaannya.

\section{Kriteria Pemilihan Media}

Sebagai seorang guru, harus dapat menentukan media yang tepat sekaligus dapat menjangkau seluruh siswa dengan keterbatasan trainer atau modul yang ada di sekolah. Kriteria yang perlu dipertimbangkan guru dalam memilih media pembelajaran menurut Nana Sudjana (1990) adalah: 1) ketepatan media dengan tujuan pengajaran, 2) dukungan terhadap isi bahan pelajaran, 3) kemudahan memperoleh media, 4) keterampilan guru dalam menggunakannya, 5) tersedia waktu untuk menggunakannya, dan 6) sesuai dengan taraf berfikir anak. Sejalan dengan hal itu Azhar Arsyad (1997) mengemukakan bahwa kriteria dalam memilih media yaitu : 1) sesuai dengan tujuan yang ingin dicapai, 2) tepat untuk mendukung isi pelajaran, 3) praktis, luwes, dan tahan, 4) guru terampil menggunakannya, 5) pengelompokan sasaran, dan 6) mutu teknis.

Dari beberapa pendapat diatas, dapat dirangkum bahwa pendapat-pendapat tersebut memiliki kesamaan dan saling melengkapi. Dapat dijabarkan menurut penulis hal yang perlu dipertimbangkan dalam pemilihan media yaitu tujuan pembelajaran, efektif, mudah diperoleh, peserta didik, penggunaan, tidak kaku, biaya, dan kualitas. Secara jelas digambarkan sebagi berikut : 1) tujuan pembelajaran, dalam memilih media seyogyanya dapat menunjang pencapaian tujuan pembelajaran yang telah direncanakan 
sebelumnya, 2) efektif, media pembelajaran menjadi yang paling efektif untuk digunakan dibanding menggunakan media yang lain, 3) mudah diperoleh, bahan yang digunakan untuk membuat media apakah mudah diperolah atau media yang digunakan sudah tersedia, 4) peserta didik, media pembelajaran yang digunakan, sesuaikan dengan kemampuan peserta didik secara rata-rata, jadi dapat menjangkau peserta didik yang memang mudah menyerap materi maupun yang lebih lambat dapat menyerap materi yang diberikan, 5) penggunaan, guru maupun peserta didik mudah untuk menggunakan, karena media yang baik adalah yang mudah digunakan dan dimengerti oleh orang awam sekalipun, 6) tidak kaku, unsur ergonomic juga perlu dipertimbangkan agar media dapat digunakan diberbagai saat dan tidak berbahaya bagi penggunanya, 7) biaya, anggaran yang harus dikeluarkan untuk membuat atau memperoleh media tersebut, jangan sampai media sebagai alternatif justru lebih mahal daripada trainer atau modul yang digunakan, 8) kualitas, perlu diperhatikan kualitas dari media yang digunakan, dengan kualitas yang baik, media juga akan bertahan lebih lama.

\section{Pembuatan Media Pembelajaran}

Sebelum membuat media pembelajaran, ada tahapan yang harus dilakukan, untuk menghasilkan media yang dapat menutupi kekurangan trainer atau modul praktikum yang digunakan sekaligus dapat menjangkau seluruh peserta didik. Tahapan yang perlu diperhatikan dalam membuat media pembelajaran adalah: 1) menentukan konsep dan bentuk media pembelajaran, 2) menentukan kompetensi dasar yang akan dicapai siswa, 3) menentukan materi yang akan dimuat dalam media pembelajaran, 4) Menentukan evaluasi yang digunakan untuk mengetahui sejauh mana keberhasilan media pembelajaran yang digunakan.

Dalam hal ini, pembuatan media pembelajaran dengan menggunakan Augmented
Rreality, dibutuhkan beberapa perangkat lunak maupun perangkat keras sebagai penunjang.

\section{Perangkat Lunak}

Perangkat lunak (Software) merupakan program dasar pada komputer yang menghubungkan pengguna dengan perangkat keras (Hardware) komputer. Secara sederhana, perangkat lunak dapat dikatakan sebagai alat penerjemah perintah-perintah untuk diteruskan ke perangkat keras.

\section{Android}

Android merupakan sistem operasi besutan raksasa internet Google yang bekerjasama dengan Open Handset Alliance. Diperkenalkan pertama kali pada tahun 2007, Android menjadi sistem operasi terbuka yang dapat dikembangkan oleh semua orang. Menurut Nazrudin Safaat (2010) Android merupakan sistem operasi perangkat mobile berbasis linux yang mencakup sistem operasi, middleware dan aplikasi. Sistem operasi Android menggunakan Java sebagai bahasa pemrogramannya.

Sejak diluncurkan, Google telah mengeluarkan Android dalam beberapa tingakatan atau versi, yaitu: 1) Android versi 1.1, menjadi Android pertama yang diluncurkan, 2) Android versi 1.5 yang diberi nama Cupcake, 3) Android versi 1.6, yang diberi nama Donut, 4) Android versi 2.1, yang diberi nama Éclair, 5) Android versi 2.2 yang diberi nama Froyo atau Frozzen Yogurt, 6) Android versi 2.3, yang diberi nama Gingerbread, 7) Android versi 3.0/3.1 yang diberi nama Honeycomb, 8) Android versi 4.0 yang diberi nama Ice Cream Sandwich, 9) Android versi 4.3 yang diberi nama Kitkat, 10) Android versi 5.0 yang diberi nama Lolipop.

\section{Vuforia}

Vuforia merupakan perangkat lunak yang dikembangkan oleh Qualcomm untuk mendukung dalam pembuatan Augmented Reality. Vuforia menggunakan sumber yang berupa target konsisten mengenai komputer vision yang fokus pada image recognition. 
Menurut Mario Fernando (2013) terdapat beberapa jenis target pada Vuforia, yaitu: 1) Image Target, misalnya: foto, halaman majalah, sampul buku, poster, kartu ucapan, 2) Frame Markers, tipe frame gambar dua dimensi dengan pola khusus yang dapat digunakan sebagai permainan, 3) Multi-target, contohnya kemasan produk atau produk yang berbentuk kotak maupun persegi, jenis ini dapat menampilkan gambar sederhana Augmented Reality dalam bentuk tiga dimensi, 4) Virtual Button, yang dapat membuat tombol sebagai daerah kotak sebagai sasaran gambar.

Agar dapat bekerja dengan baik, vuforia SDK memerlukan beberapa komponen penting. Komponen terebut antara lain kamera, image converter, tracker, video background render, application code, trackables, dan marker. Seluruh komponen tersebut digunakan untuk membangun sebuah aplikasi berbasis Augmented Reality.

\section{Perangkat Keras}

Perangkat keras merupakan alat dalam bentuk fisik yang dapat digunakan untuk mengolah perangkat lunak. Perangkat keras yang digunakan meliputi:

\section{Komputer atau laptop}

Komputer atau laptop menjadi barang yang umum saat ini, setiap guru diwajibkan untuk dapat menggunakan komputer sebagai bagian dari kompetensi guru yang harus dimiliki. Komputer merupakan seperangkat elektronik yang terdiri dari monitor, papan ketik, mouse, dan CPU. Komputer dapat digunakan untuk menulis dokumen, melakukan perhitungan matematis secara kompleks, video editing, programming, game, image editing, dan berbagai kemampuan canggih lainnya. Laptop merupakan perangkat komputer portable, sehingga dapat dibawa kemanapun. Penggunaan laptop tidak terpaku pada satu tempat saja. Spesifikasi komputer yang digunakan untuk membuat Augmented Reality tidak menuntut untuk spesifikasi yang terlalu tinggi. Spesifikasi minimal komputer yang digunakan adalah Prosessor Core I3, RAM 3GB, HDD 320 GB, Sistem operasi Windows 7 sudah dapat membuat media pembelajaran menggunakan Augmented Reality.

\section{PEMBUATAN APLIKASI}

Menurut Eka Legya (2015:39-41), dalam membuat aplikasi, ada tahapan-tahapan yang harus dilalui. Hal ini dilakukan agar aplikasi media media pembelajaran yang dibuat akan bekerja secara optimal sesuai dengan target perencanaan. Tahapan yang harus dilakukan adalah:

\section{Tahap Pengumpulan Spesifikasi Kebutuhan Pengguna.}

\section{Analisis Kebutuhan}

Pada tahap ini, dilakukan identifikasi kebutuhan apa saja yang diperlukan dalam perancangan media pembelajaran. Guru perlu melakukan observasi terhadap mata pelajaran yang akan diajarkan, kompetensi dasar yang ingin dicapai, kemampuan siswa dalam menggunakan, dan kemanfaatan aplikasi sebagai penunjang kegiatan praktikum.

\section{Analisis Perangkat Keras}

Tahap analisis perangkat keras, adalah melakukan identifikasi spesifikasi perangkat keras yang akan digunakan untuk membangun media pembelajaran, dan menjalakan media pembelajaran sebagai uji coba awal. Analisis perangkat keras meliputi spesifikasi perangkat keras komputer, dan spesifikasi smartphone.

\section{Analisis Perangkat Lunak}

Perangkat lunak sebagai penunjang dalam pembangunan media pembelajaran perlu diidentifikasi. Perangkat lunak yang dibutuhkan dalam membangun media pembelajaran ini antara lain: Unity 3D, Vuforia SDK, Java JDK, Corel Draw X7, Adobe Photoshop CC2015, Format Factory, StarUML.

\section{Tahap perencanaan arsitektur sistem}

Pada tahap ini, dilakukan perancangan arsitektur sistem yang akan dibangun. Rancangan sistem digambarkan dalam use case 
diagram, activity diagram, dan sequence diagram.

\section{Tahap Perancangan Komponen Sistem}

Komponen dalam aplikasi media pembelajaran dirancang dalam tahap ini. Perancangan mengacu pada analisis kebutuhan, analisis perangkat lunak, analisis perangkat keras, dan perencanaan arsitektur sistem. Rancangan aplikasi dibuat dalam sebuah storyboard. Storyboard merupakan gambaran secara visual tampilan media pembelajaran dalam bentuk sketsa.

\section{Tahap Pembuatan Disain Antar Muka}

Antar muka dibuat berdasarkan perancangan disain antar muka. Antar muka dibangun berdasarkan storyboard yang telah dibuat pada tahan perancangan disain antar muka. Pada tahap ini software disain grafis digunakan dalam pembuatan disain antar muka. Software yang digunakan adalah Corel Draw X7 dari Corel Corporation dipadukan dengan Adobe Photoshop CC2015 dari Adobe. Corel Draw digunakan untuk membuat disain tampilan pada media yang meliputi background, tombol, soal, halaman kompetensi dasar, halaman Augmented Reality, halaman materi, halaman evaluasi, dan halaman profil. Adobe Photoshop digunakan untuk membuat icon lalu mengkonversi menjadi format portable network graphic (png). Berikut disain komponen antar muka yang ada dalam media pembelajaran.

\section{Icon}

Icon menunjukkan gambar kecil untuk mewakili aplikasi media pembelajaran dalam menu utama. Icon biasa terdapat pada menu utama smartphone.

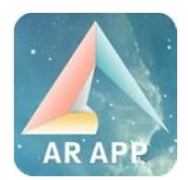

Gambar 13. Icon pada aplikasi media

\section{Splash Screen}

Splash screen merupakan halaman muka yang pertama kali muncul. Halaman ini muncul ketika aplikasi dijalankan untuk menandakan aplikasi mulai bekerja.

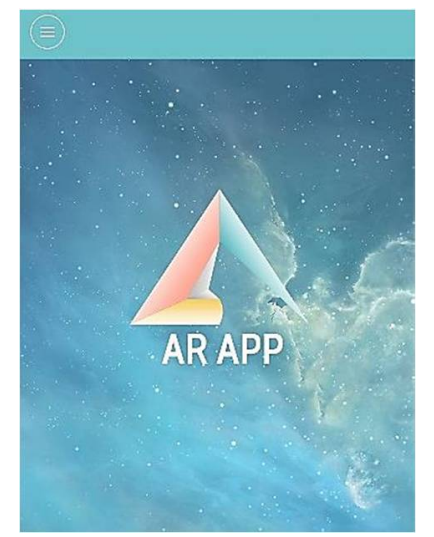

Gambar 14. Tampilan splash screen

\section{Halaman Menu Utama}

Merupakan halaman menu utama dalam media pembelajaran yang dapat diakses oleh pengguna. Menu yang terdapat dalam halaman ini adalah kompetensi dasar, augmented reality, materi, dan evaluasi. Menu kompetensi dasar untuk menunjukan kompetensi yang harus dicapai setelah mempergunakan media pembelajaran ini. Menu Augmented Reality, menu yang merupakan hasil penggabungan dari benda maya dengan benda nyata dalam satu waktu yang bersamaan. Menu materi, untuk mendukung menu Augmented Reality agar peserta didik lebih mudah memahami materi yang disajikan. Menu evaluasi, sebagai evaluasi mandiri yang dilakukan oleh peserta didik, untuk mengetahui sejauh mana keterserapan materi yang disampaikan melalui media yang digunakan.

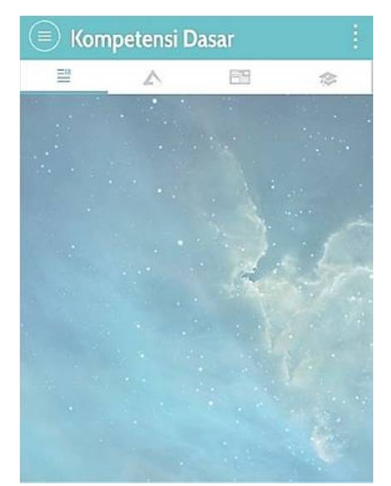

Gambar 15. Menu Kompetensi Dasar 


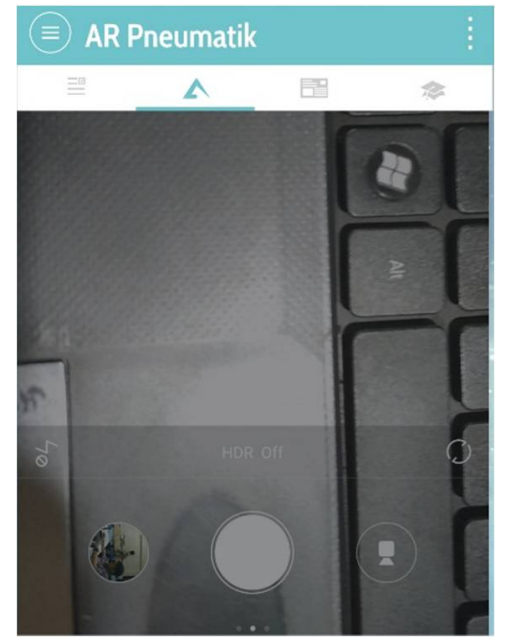

Gambar 16. Menu Augmented Reality

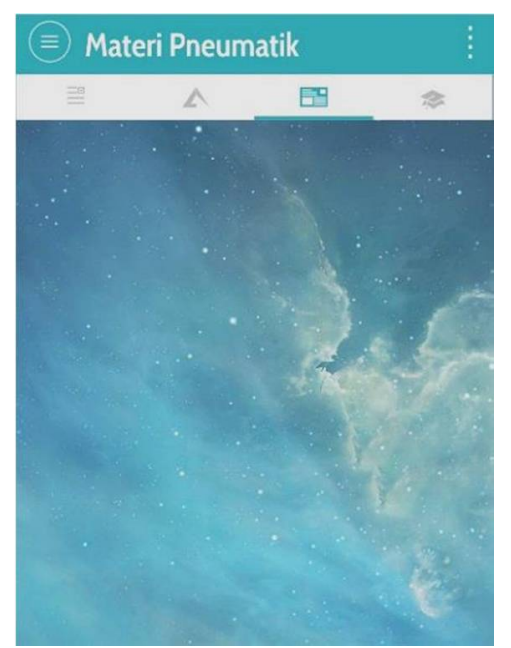

Gambar 17. Menu Materi

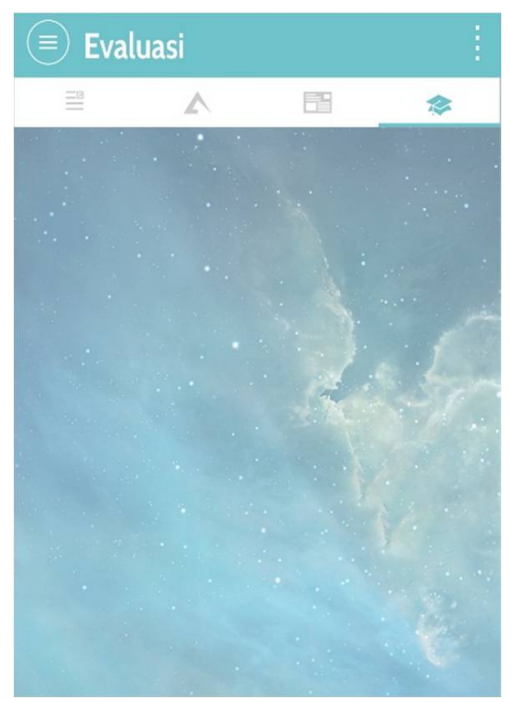

Gambar 18. Menu Evaluasi

\section{Halaman profil}

Halaman ini menunjukkan biodata singkat pengembang media pembelajaran. Halaman ini dapat pula berisi cara penggunaan aplikasi serta keterangan tambahan.

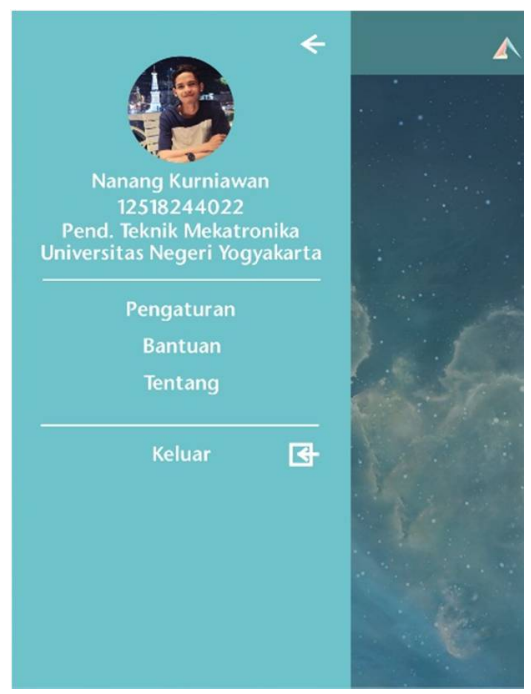

Gambar 19. Halaman profil pengembang

\section{Tahap Pembuatan Program}

Proses pembuatan program adalah penyatuan dari tahap pembuatan disain antar muka dengan berbagai aplikasi dalam bahasa pemrograman. Hasil akhir dari tahap ini adalah sistem yang mempunyai fungsionalitas sesuai dengan yang diharapkan. Langkah yang perlu dilakukan pada tahap ini adalah : 1) persiapan asset, yaitu memasang Unity 3D sebagai software utama pada komputer, 2) pembuatan marker, sebai penanda obyek maya akan dipasang, 3) mengunggah marker yang dibuat ke Vuforia untuk dilakukan verifikasi 4) membuat proyek baru di Unity 3D.

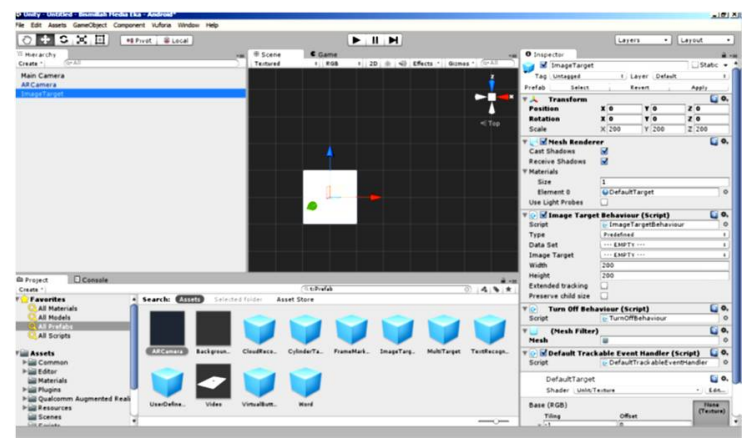

Gambar 20. Tampilan proyek Unity3D

Dimulai dari pembuatan menu utama dengan meng-import disain yang telah dibuat 
ke proyek Unity 3D. Action diberikan ke setiap tombol untuk dapat bekerja ketika tombol ditekan. Pemrograman terus dilakukan hingga seluruh disain dapat dijalankan pada perangkat smartphone.

\section{Tahap Pengujian}

Pada tahap yang terakhir adalah melakukan pengujian aplikasi yang telah selesai dilaukan pemrograman. Pengujian dilakukan dengan cara debugging aplikasi kedalam smartphone, untuk mengetahui tingkat keberhasilan aplikasi saat digunakan. Aplikasi diujicoba pada berapa tipe smartphone yang berbeda. Hal ini dilakukan untuk menguji keandalan aplikasi saat dipergunakan diberbagai tipe smartphone yang berbeda.

\section{SIMPULAN}

Dari uraian diatas, dapat ditarik beberapa kesimpulan. Media pembelajaran menjadi hal yang tidak terpisahkan dalam sebuah pembelajaran. Hal ini dikarenakan keberhasilan materi yang disampikan oleh guru turut dipengaruhi oleh media pembelajaran yang digunakan. Di era yang modern ini, media pembelajaran tentu sangat mudah didapatkan. Disamping mudah untuk mendapatkan, perlunya kejelian dalam memilih media yang digunakan. Media harus dapat menjangkau seluruh siswa dan menjadi solusi alternatif kurangnya modul praktikum di SMK.

Melaui Augmented Reality, guru dapat membuat media pembelajaran yang menyenangkan, interaktif, dan mudah digunakan. Augmented Reality juga dapat menggantikan modul pembelajaran yang belum ada di sekolah dalam bentuk virtual atau maya. Siswa tetap dapat melihat dan menggunakan modul seperti modul aslinya, namun dalam bentuk virtual. Melaui terobosan baru ini, semakin banyak variasi media pembelajaran yang dapat dibangun untuk mendukung kegiatan pembelajaran di sekolah, terutama SMK yang membutuhkan modul pembelajaran praktikum.

\section{SARAN}

Diharapkan di masa mendatang, dengan semakin canggihnya teknologi, sudah tidak ada lagi keterbatasan media pembelajaran. Guru dapat lebih berinovasi membuat media pembelajaran agar siswa lebih tertarik untuk mengikuti kegiatan belajar mengajar.

\section{DAFTAR RUJUKAN}

Azhar Arsyad. (1997). Media Pengajaran. Jakarta: Raja Grafindo Persada.

Bethany. 2014. Teknologi dan Media Pembelajaran. Diakses dari http://sttbethany.blogspot.com/2014/10/ media-pembelajaran.html. pada tanggal tanggal 9 Maret 2016, pukul 09.30 WIB.

Detik.com. 2015. Diakses dari http://inet.detik.com/read/2015/06/17/145 016/2944945/654/takcumavirtualrealitya ugmentedrealitypundijabani. tanggal 16 Februari 2016, pukul 15.14 WIB.

Eka Legya F. 2015. Pengembangan dan Analisis Media pembelajaran Perakitan Komputer Berbasis Augmented Reality untuk Platform Android di SMK YPKK 1 Sleman. Laporan Penelitian. Universitas Negeri Yogyakarta

Elisa Usada. 2014. Rancang Bangun Modul Praktikum Teknik Digital Berbasis Mobile Augmented Reality (AR). Jurnal Infotel. 6(2). Hlm. 83-88.

Fernando Mario. 2013. Membuat Aplikasi Android Augmented Reality Menggunakan Vuforia SDK dan Unity. Solo. Buku AR Online.

I Dewa Gede W. D., I Ketut Gede D. P. \& Ni Made Ika M. M. 2015. Aplikasi Augmented Reality Magic Book Pengenalan Binatang untuk Siswa TK. Jurnal Lontar Komputer. 6(2). Hlm. 589596. 
N.R Raajan. et al. 2014. A Review on: Augmented Reality Technologies, System and Applications. Jurnal Asian Network for Scientific Information. 14(14). Hlm. 1485-1486.

Nazruddin Safaat. 2012/Edisi Revisi. Pemrograman Mobile Smartphone dan Tablet PC Berbasis Android. Infromatika. Bandung.

Republika.co.id. 2015. Diakses dari http://rendtek.republika.co.id/berita/tren dtek/aplikasi/15/10/22/nwlikh280augmen tedrealityefektifbantupengembanganpela kuukm. tanggal 3 Februari 2016, pukul 14.02 WIB.
Ronald T. Azuma. 1997. A Survey of Augmented Reality. Jurnal Teleoperators and Virtual Environments 6. Hlm. 355385 .

Rudi Susilana \& Cepi Riyana. 2009. Media Pembelajaraan, Hakikat, Pengembangan, Pemanfaatan, dan Penilaian. Wahana Prima. Bandung.

Sigit Ady P. 2014. Augmented Reality Tata Surya sebagai Sarana Pembelajaran Interaktif Bagi Siswa Sekolah Dasar Berbasis Android. Laporan Penelitian. Universitas Muhammadiyah Surakarta. 